\title{
The Use of Web 2.o Tools in the Foreign Language Classroom
}

\author{
Tawffeek A. S. Mohammed \\ Associate Professor, \\ IPSA, South Africa
}

Blanche Nyingome Assam

\author{
Lecturer, \\ Department of Foreign Languages, \\ UWC, South Africa \\ Mustapha Saidi \\ Lecturer, \\ Department of Foreign Languages, \\ UWC, South Africa
}

\section{Doi: 10.36941/jesr-2020-0o37}

\begin{abstract}
The present study aims to investigate the role that Web 2.o tools can play in the enhancement of productive and receptive language skills of students of Arabic as a foreign language. The study is part of an ongoing project on the integration of Web 2.0 tools in teaching Arabic as a foreign language and the attitudes of the learners towards them. The design of the study is pre-post, experimental-control group. The sample consisted of (30) students: an experimental group $(n=15)$ and a control group $(n=15)$, doing their BA in Arabic and Islamic Studies at the International Peace College South Africa (IPSA). The experiment took place in the Language Skills module for 12 weeks. A technology-enhanced programme that utilises a myriad of Web 2.0 tools was used in teaching the experimental group. The control group students, however, were taught using a traditional teaching methodology in a brick-and-mortar classroom and they did not receive any technologyenhanced instruction. The study concluded that the use of Web 2.0 tools has contributed to the enhancement of the language skills and vocabulary of the students. The findings indicated that there was a significant statistical difference between the scores of the two groups in the language skills and vocabulary post-test in favour of the experimental group.
\end{abstract}

Keywords: Web 2.o tools, language skills, Arabic as a foreign language (AFL), vocabulary

\section{Introduction}

Technology plays a vital role in all aspects of life. Its use is no longer confined to scientific and technical fields, but it has been widely used in humanities. However, despite the significance of technology in education, it was not given the pride of place it deserves in the educational syllabus at schools and universities especially in third world countries. A cursory look at the content of the Arabic language modules at many South African universities, for instance, shows clearly that the 
syllabi do not keep abreast with the rapid technological developments in the field of computerassisted language learning (CALL). We do not exaggerate if we say that teaching Arabic as a foreign language (TAFL) is still in its infancy. Unfortunately, Arab universities do not pay adequate attention to this field in the way that Western universities promote their home languages such as English and French. Even worse, some Arab universities opened language centres in which several foreign languages are taught, and they do not take any practical steps for teaching Arabic as a second or a foreign language.

Commenting on the current situation of teaching Arabic as a foreign language (TAFL), Mohammed (2011:3) rightly pointed out that Western universities in England and the United States of America took the initiative of opening fully-fledged departments for teaching Arabic as a foreign language. In a similar vein, a considerable number of Arabic departments have been opened over the last few years in countries such as Turkey, Malaysia, South Africa, Iran, India, Germany, etc. as independent departments or as part and parcel of Islamic studies colleges and departments.

In South Africa, Arabic is taught at the undergraduate and postgraduate levels at a number of public and private universities such as the University of Cape Town, the University of the Western Cape, University of South Africa, University of Johannesburg, the international Peace College South Africa, Al-Madina College and others. It may be argued that the grammar translation method is commonly used in the foreign language classes. Students are frequently asked to read a text, translate new words and do some grammar. New teaching methods need to be adopted with a view to enhancing the linguistic competence of the learners. Undoubtedly, technology-enhanced instruction has made the use of some language teaching methods such as communicative method and Content and Language Integrated Learning (CLIL) more effective. The present paper investigates the integration of Web 2.0 tools in teaching language skills as well as vocabulary. It is believed that those Web 2.o tools will continue to play a dominant role in the foreign language classroom. The fourth industrial revolution technologies (4IR) have given new momentum to these tools. That is, these tools have become more accessible through user-friendly mobile applications.

\section{From CALL to MALL}

The field of applied linguistics in general and language technology-enhanced learning in particular have witnessed tremendous changes over the last few decades. Computer-assisted language learning (CALL) has been in use since the sixties of the $20^{\text {th }}$ century (Marty, 1981). However, the rapid developments in the field of mobile technology has led to the emergence of a new approach to language teaching and learning known as Mobile Assisted Language Learning (MALL). This mode of technology is expected to surpass CALL for a number of reasons including affordability, accessibility and functionality of mobile devices. By the end of 2012, the number of mobile devices was estimated to exceed the world's population (Cisco, 2012). A recent report shows that "In 2017, the number of mobile-connected tablets increased $14 \%$ to 176 million, and the number of mobile-connected PCs increased $1 \%$ to 135 million" (Cisco, 2019: 4). That prompted manufacturing companies to adopt a wide host of mobile-friendly communication and learning apps. However, UNESCO expressed its concern that "mobile learning has so far failed to have a significant long-term impact on education" (UNESCO, 2017).

In fact, mobile technology can be perfectly utilized to provide quality education to all learners. Foreign language education and MALL technology are likely to co-evolve in mutually supportive ways. Developments and changes in technology are important as long as they can push foreign language pedagogy forward. MALL can greatly contribute to that. It does not only facilitate the accessibility of learning materials or interaction between students, teachers and peers but it also facilitates real-time collaboration, long-scale social interaction, creativity, personalization of learning and scaffolding learning activities. The technological sophistication of mobile devices in general and their reliable and speedy internet features have added an impetus to the rise of MALL. Mobile and computing devices with internet connection such as iPhone or Samsung Galaxy, and tablets like the 
Google Nexus and iPad have put thousands of user-friendly tools/apps at the disposal of the language teacher and learner. A category of mobile tools that are expected to dominate the landscape of language learning is Web 2.0 tools.

\section{Web 2.o Tools}

Web 2.o tools can be defined as internet tools that enable the user to create content and interact with other users. They therefore differ from Web 1.o tools which allow the user to receive information through the web. The user is no longer a passive receiver or consumer of information; $s /$ he is rather an active producer of content. The emergence of Web 2.0 tools has positively influenced all spheres of life and education has attained the lion's share of these tools.

O'Reilly (2005) differentiated between Web 1.0 and Web 2.0 saying that the former is concerned with connecting computers and making technology more efficient for computers. Web 2.0 tools, on the other hand, are concerned with connecting people and making technology more efficient for them. Hence interactivity is what distinguishes this generation of web tools from their predecessors. We can safely argue that e-learning and virtual learning environments (VLEs) are mostly based on the technology invested in Web 2.0 tools. Some of the educational benefits of these tools can be briefly stated below.

Web 2.0 tools revolve around the concept of active learning. A learner is no longer a mere receiver of information through the web but rather s/he is highly encouraged to interact and create content, share it and collaborate with others. Web 2.0 tools can therefore facilitate crowd sourcing and help foster a community of learning and harness the "wisdom of the crowd" (Surowiecki, 2005). As Hew \& Cheung (2013) pointed out, Web 2.0 tools and social media platforms allow students and teachers to connect with like-minded people, or experts in their field, and that ultimately leads to the enhancement of their learning experience. This connection can constitute a community of learners supporting one another (Light \& Polin, 2010).

Furthermore, the use of Web 2.0 tools gives more space for discussion and learning about topics that might not be part of the syllabus. Collaboration can help learners to delve into topics or discussions they have not been interested in before. Another salient feature of those tools lies in the fact they can shift the roles of the learner and the teacher in the classroom. They can be incorporated to the syllabus with a view to creating a learner-centred classroom and reducing reliance on the traditional teacher-centred instruction. A teacher is no longer a sage on the stage or a preacher in the pulpit but a tutor, a guide and a facilitator of the learning process.

We concur with Light \& Polin (2010), who pointed out that Web 2.0 tools could transform education should they are used properly and aligned with the objectives of a lesson or a module. Web 2.o tools can be effectively used to enhance the linguistic competence of foreign language learners. In addition, the use of such tools can be the ideal means to enhance what is known today as the $21^{\text {st }}$ century skills including creativity, communication, collaboration and critical thinking.

Based on the above advantages, education technology and software industries have exerted great efforts to ensure the optimal use of these tools. Those efforts were culminated in the introduction of Learning Tools Interoperability ${ }^{\mathrm{TM}}$ (LTI) which has made the integration of internetbased learning applications with online platforms possible. LTI creates a seamless way of launching external Web 2.o tools, which are often provided and hosted remotely through third-party services, with leading learning management systems such as Moodle, Canvas, NEO and Blackboard. The LTI specification also serves as a mash-up solution widely used in the field of software as a service (SaaS).

However, the use and selection of Web 2.0 tools should be based on solid criteria. We have thousands of Web 2.o tools at our disposal today. These tools are subject to change, development, improvement and even disappearance. Some of them might be available for free and at a later stage they require subscription; a thing that is likely to create a problem for learners/institutions that cannot afford the cost. The 'think before you leap' proverb is applicable in this scenario. Teachers should not be impressed by the advantages of a Web 2.0 tool alone. They need to consider the 
reliability of the tool and all its pros and cons in terms of affordability and ease of use. The review of tools by other teachers can help in this regard. Once the tool passes the reliability test, other selection criteria need to be considered. A teacher should think to what extent the selected Web 2.0 tool may enable the learners to achieve the objectives of the lesson and enhance their learning experience. A teacher is also required to check to what extent the selected tool may motivate the learners and foster their collaboration.

\section{Statement of the Problem}

It is undeniable that Arabic has gained an international attention and it is currently taught as a second or a foreign language in several countries. Arabic has also been given greater systematic attention in the localization and translation industry. Arabic and Chinese have topped the list of world languages in so far as the internet content is concerned as reported by the SDL Trados report (Trados, 2015). According to the report, the use of Arabic in internet content has increased twenty times between 2000 and 2010. Yet, Arabic is sometimes taught in a traditional manner in a teachercentred setting. This study aims to find out to what extent the use of Web 2.0 tools can enhance the linguistic competence of the learners of Arabic as a foreign language. In particular, it aims to find out whether the use of such tools can enhance the receptive and productive skills of the learners and their $21^{\text {st }}$ century skills in general.

\section{Hypotheses}

The study aims to test the following hypotheses:

i- The use of Web 2.o tools can enhance the language skills (i.e., reading, writing, speaking and listening) as well as the vocabulary of the learners of Arabic as a foreign Language.

ii- There is no statistical significance at $\mathrm{p} \leq 0.05$ in the scores of the control group, which was taught in a traditional manner and the experimental group, with which the intervention was used in the achievement post-test.

\section{Literature Review}

There is a considerable number of studies that dealt with the use of Web 2.o tools in the teaching of foreign languages. The majority of these studies focused on the use of a specific Web 2.o tool in the enhancement of a particular language skill such as the use of Twitter in writing. Compared to other languages, Arabic has not attracted enough attention in this field in proportion to its religious, economic, geo-political and international significance. In fact, there are few studies that investigate the role of Web 2.o tools in teaching Arabic as a foreign language. In what follows, we survey some of these studies.

Ghalib \& Sabri (2012) investigated the use of multi-media in teaching Arabic as a second or a foreign language. The study concluded that using multimedia has enabled teachers to plan the outline of their courses easily. Similarly, Rabii (2017) discussed the use of mass media and modern technology in teaching Arabic to non-native speakers. The study concluded that teaching Arabic language in the era of globalization faces many challenges that can be solved through the effective use of media and information technology in a way that preserves its religious significance.

Abdullah (2015) dealt with the attitudes of students and teachers in Brunei Darussalam towards using social media platforms in teaching Arabic. Using descriptive analytical methods and questionnaires given to 39 teachers and students from various universities in Brunei, the results showed that the trend in using social media platform in teaching Arabic was high. The study concluded that $70 \%$ of the respondents with the mean of 3.7401 confirmed that they used them in teaching, $76.6 \%$ with the mean of 3.8376 were using them as feedback tools and $78 \%$ used them for promoting language skills. The overall scores were also high and significant. The study recommended 
that social media platforms should be fully utilized to develop methods for teaching Arabic and that syllabus design should take into consideration how to best incorporate this new approach.

Shehreer \& Abdul-Ghani (2016) designed a computer courseware in teaching Arabic language via website for students with the specialization of tourism at Poly-Tech College of Mara at Kelantan Darul Naim, Malaysia. The study aimed to help students to learn Arabic for tourism purposes and a special website was developed for this purpose. The learning materials were designed on the basis of ADDIE instructional model. The study indicated that the majority of the students found it useful to learn Arabic for tourism purposes via the designed website. It motivated the students to learn Arabic and it fostered the sense of learner autonomy among them.

Abdul-Hameed \& Khawalidah (2018) investigated the attitudes of university students in Malaysia towards using an educational programme based on collaborative learning via social networking in improving Arabic language writing. The sample of the study included 25 students at the International Islamic University Malaysia in the academic year 2014/2015. Students were asked to respond to a questionnaire. The results showed that students developed positive perceptions towards the use of the proposed educational programme in improving writing skills. The study recommended the use of collaborative learning via social networking while teaching writing.

As for the studies that investigated the use of Web 2.0 tools in teaching foreign languages other than Arabic, Blattner \& Lomicka (2012) conducted a study on Facebooking and social generation in an intermediate French class. The study concluded that students identified various pedagogical and social benefits for the integration of Social Networks Services (SNS) in their classrooms in general and Facebook in particular. In a similar vein, Mc Dermott (2013) investigated the role of social media in the teaching of French as a foreign language. The study concluded that students took some time to adapt to the use of social networks in an educational context. The study used the Moodle forums, which students use as their learning management system as the main tool. Students were also instructed to create an external blog using WordPress and a Facebook page was used for communication. The study concluded that the majority of students engaged with the learning opportunities provided by the above tools and used them to enhance their language skills.

In so far as the use of Web 2.0 tools in teaching English as a foreign language (EFL) is concerned, some studies investigated the role of micro-blogging and wikis in developing the writing skills of the learners (Kessler, Bikowski, \& Boggs, 2012; Lee, 2010; Vurdien, 2013). Other studies investigated the use of Twitter to enhance the communicative and cultural competence of learners (Borau, Ullrich, Feng, \& Shen, 2009) and the use of YouTube and blogs for meta-cognitive learning, self-regulated learning and autonomous learning (Hafner \& Miller, 2011). Other scholars explored the valuable use of digital storytelling (Brenner, 2014; Robin, 2008) and gamification (Flores, 2015) in motivating learners and developing their various language skills. By the same token, Reinhardt, Warner, \& Lange (2014) dealt with the use of commercial games as L2 learning resources. The researchers developed a project to explore game-enhanced, literacies-informed instruction in teaching German as a second language at a college-level in the United States. The study concluded that gaming literacy does not only mean the ability to play games (Zimmerman, 2008:30) but it develops other literacies such as systems thinking and design. Those literacies may be applicable to language development more broadly.

The applicability of Web 2.0 tools was also investigated in disciplines other than language learning. Sandars \& Schroter (2007), for instance, investigated the use of Web 2.0 technologies by medical undergraduate students in the United Kingdom. The study concluded that although Web 2.0 tools were widely adopted by institutions, the use of such tools (e.g. Podcasts) was still marginal. Likewise, Azab, Abdelsalam, \& Gamal (2013) investigated the use of Web 2.0 at Egyptian public universities. The results indicated that blogs, wikis and social networks were widely used by students and academic staff. They were mainly used for sharing academic content and research activities. The study recommended that awareness programmes to train and familiarize students and academics with existing or new tools should be conducted regularly. Similarly, Augustsson (2010) investigated the use of a Web 2.0 tool known as VoiceThread for collaborative activities by undergraduate 
psychology students. The study found that VoiceThread was used to support students' reflections concerning their own and their friends' thoughts and emotions.

In a nutshell, a considerable number of studies have dealt with the use of computer and technology in teaching Arabic as a foreign language. The significance of the current study stems from the fact that it is the first study as far as we are aware that deals with teaching Arabic as a foreign language in the South African context. Besides, a cursory glance at the above studies shows that most of them are theory-oriented and they have not applied Web 2.0 tools in the foreign language classroom. In a study carried out by Luo (Luo, 2013), it was found that 43 studies dealt with the use of Web 2.0 tools in education, two of them only were empirical. Our study is empirical and part of a broader action research project that explores the benefits of those tools in teaching/learning a foreign language and the attitudes of the learners to them. The study is also based on a solid conceptual framework that incorporates a number of pedagogical theories and technological frameworks, as is stated below.

\section{Theoretical Framework}

The study used an eclectic approach that is based on Chickering and Gamson's seven principles of good practice in undergraduate education (Chickering \& Gamson, 1989), Bloom's taxonomy of educational objectives (Bloom, 1956) and Puentedura's SAMR model (Puentedura, 2013) for the integration of technology in learning. In what follows, we briefly state these theoretical and conceptual issues and how we have used them in the study. Chickering and Gamson's theory (Chickering \& Gamson, 1989) identified seven principles of good practice in undergrdauate education as follows:

i- Encourages contact between students and faculty.

ii- Develops reciprocity and cooperation among students.

iii- Encourages active learning.

iv- Gives prompt feedback.

v- Emphasizes time on task.

vi- Communicates high expectations.

vii- Respects diverse talents and ways of learning.

Our selection of the above theory is motivated by its direct connection to undergraduate education. In addition, the above seven principles constitute a theoretical framework that enables us to categorize the huge bulk of Web 2.0 tools available today according to their function (i.e., communication, collaboration, production or assessment tools) and adapt them to the service of the educational process. However, the mere classification of tools will not be sufficient should not the teacher divide his/her lesson or unit into clear learning outcomes and objectives. Only at this stage a teacher should think of selecting Web 2.o tools that may help achieve these objectives and learning outcomes. In this regard, Bloom's taxnomoy and Puentedura's SMAR model can be benefitial. While the former is ideal for the design and formulation of learning objectives, the latter is suitable for the selection of technology. The combination of the two models will ensure an effective use of Web 2.0 tools in the foreign language classroom.

Bloom classified the different learning objectives and skills into 6 levels that can be used to structure the learning objectives, lessons, and assessments of any course, including a foreign language course. Those levels are given below: 


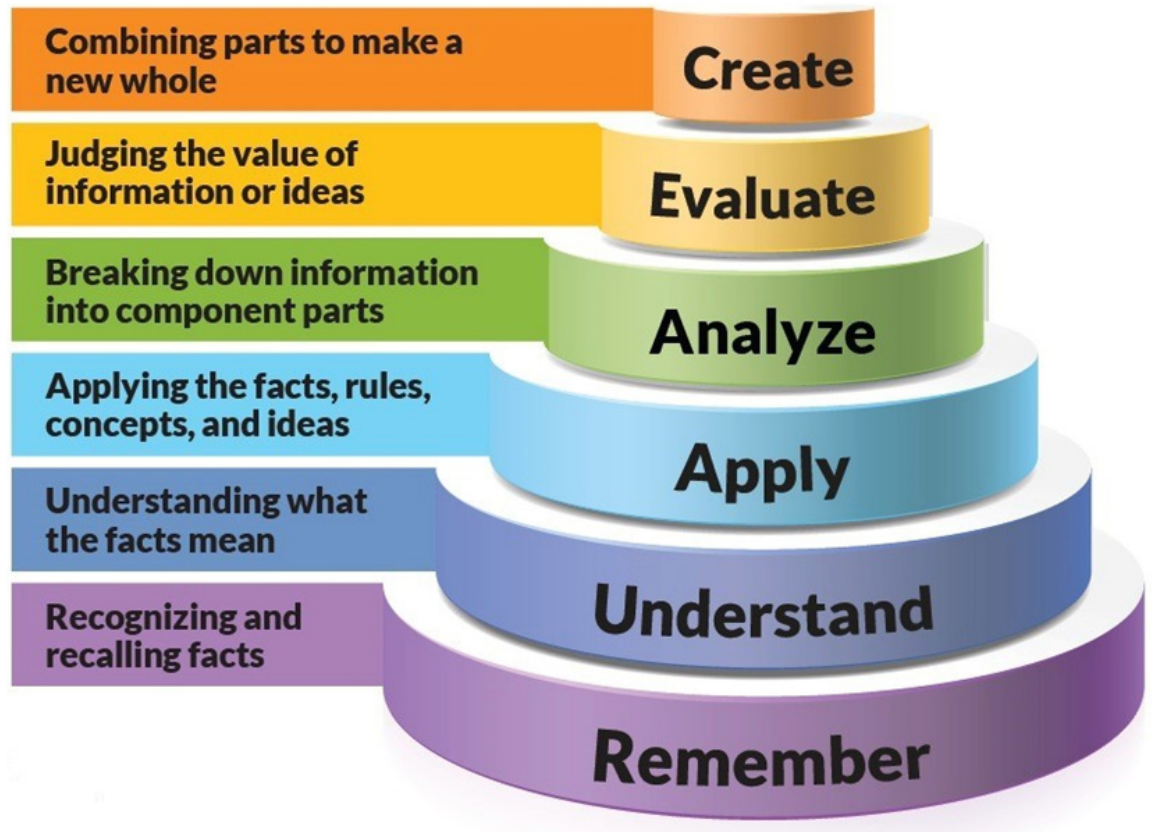

Figure 1. Bloom's Taxonomy of Learning Objectives

Remembering is concerned with retrieving, recognizing, and recalling relevant knowledge or facts from long-term memory. An example of remembering is to ask learners to answer some straightforward reading comprehension questions. In understanding, students may be asked to construct meaning from oral, written, and graphic messages. They may be asked to interpret, exemplify, classify, summarize, state, and compare. Students can also be asked to translate a text into the foreign language or simply rephrase a message using their own words. In applying, students carry out a procedure, or apply rules, concepts and ideas. A learner can for example use the expressions, colocations and idioms $\mathrm{s} /$ he has learned in new discussions or debates. S/he can also use the grammatical rules s/he learnt in similar contexts or in his/her oral and written production. At the analysis stage, teachers let the students break material into constituent parts and determine how the parts relate to one another and to an overall structure. Learners can for example analyse a reading text to a number of key ideas or hyperthemes. Analysis can also take place when learners analyse the morphological root/stem of a word with a view to understanding its meaning. As for evaluating, students may be instructed to critique and make judgments based on certain criteria and standards. In other words, learners can peer-review their composition or translation assignments using checklists and rubrics. Finally, in creating, students are encouraged to be creative. They can combine elements to create a coherent or functional whole. Learners can start creative and critical writing or digital storytelling.

In fact, Bloom's taxonomy dates to 1956. That is, it was introduced decades before the emergence of the internet and technological revolution. We have therefore decided to combine Bloom's taxonomy (Bloom, 1956) with Puentedura's SAMR model of integrating technology in education (Puentedura, 2013), which appears in the following figure. 


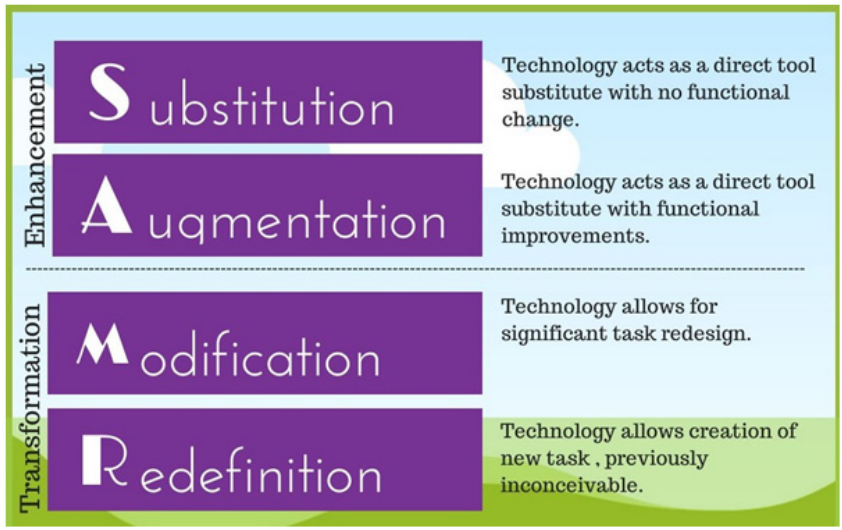

Figure 2: Puentedura's SMAR Model

The model resembles Bloom's taxonomy to a great extent. The lower level of Bloom's taxonomy can be parallel to SAMR's enhancement component, which includes substitution and augmentation. Substitution simply means the replacement of a traditional tool with a technological tool. In augmentation, technology acts as a direct tool substitute with functional improvement. In extension, the higher level of Bloom's taxonomy is parallel to SAMR's transformation level, which also consists of two phases, namely modification and redefinition. Modification is a phase in which the technology allows for a significant change. An example of modification could be the use of edpuzle to modify a YouTube video by inserting some expressions and activities in the video with an aim to learning and understanding a report or a story. Redefinition is the last phase in the model. During this phase, technology is used to create materials in ways that were previously not possible in the absence of technology (e.g. the use of Bigbluebutton for webinars and video conferencing to connect classrooms in different countries).

Hence, the integration of the two models helps us infuse technology to teaching foreign languages. It enables us to design tasks with clearly defined learning outcomes. Technology should not be used haphazardly; it should rather be used to reinforce the learning process and to achieve learning outcomes. In other words, the use of technology enables us to design an array of interesting and motivating learning activities, previously inconceivable.

SAMR model and Bloom's taxonomy were used in tandem in the current study throughout the experiment. At the substitution phase, a Web 2.0 tool such as a wiki or an e-portfolio or a website is used in place of the traditional book to assist the students with remembering activities. For understanding activities, students are provided with a Web 2.0 tool such as Wordlink that enables them to look up the new words in dozens of dictionaries in one click. Students can also use closed captions for videos to understand the gist of a report or they can use the embedded interactive quiz tools to get some hints to the answer of a particular question.

Application activities at Bloom's taxonomy are coupled with the augmentation phase of the SAMR model. That is, students are asked to use Wordlink to check the meaning of words in monolingual and bilingual dictionaries or to examine the meaning of a key word in context (KWIC) in a language corpus. Students can also do various interactive activities using the Web 2.0 tools embedded into our website.

The modification phase is coupled with Bloom's analysis level. Students are asked to write or speak about a certain topic and share their recordings or real-time writings with peers using tools such as Vocaro or google Docs.

In a similar vein, modification is coupled with creation and evaluation activities by asking students to use Wevideo to create a digital storytelling or to use a peer-review tool (e.g. Canvas) to grade and comment on the submitted assignments of their peers. 


\section{Methodology}

The study used 30 students of Arabic as a foreign language at the International Peace College South Africa (IPSA). Students were divided into two groups: one is experimental and the other is a control group. The students were distributed randomly in the two groups. The control group was taught using a traditional methodology and the other group was taught in a blended learning mode using a number of Web 2.0 tools as follows:

i- The module was divided into a number of learning units and a number of learning outcomes were prepared for each unit based on Bloom's taxonomy.

ii- Web 2.o tools that can serve various language skills and vocabulary were selected carefully. Some of those tools are given in table 1.

Table 1: Web 2.0 Tools Used in the Intervention

\begin{tabular}{|c|c|c|c|}
\hline Tool & \begin{tabular}{|l} 
Logo \\
\end{tabular} & Website & Function \\
\hline Dotsub & (d) dotsub & https://dotsub.com/ & Captioning and translating videos online. \\
\hline Vizia & Vizia & https://vizia.co/ & Integrating quizzes and polls into videos. \\
\hline Clilstore & Clilstere & $\begin{array}{l}\text { https://multidict.net/clilsto } \\
\text { re/ }\end{array}$ & \begin{tabular}{|l} 
Teaching units for Content and Language \\
Integrated Learning.
\end{tabular} \\
\hline Wordlink & Wordlink & $\begin{array}{l}\text { https://multidict.net/wordli } \\
\text { nk/ }\end{array}$ & $\begin{array}{l}\text { Linking most webpages word-by-word to online } \\
\text { dictionaries. }\end{array}$ \\
\hline Multidict & Multidînct & $\begin{array}{l}\text { https://multidict.net/multid } \\
\text { ict/ }\end{array}$ & $\begin{array}{l}\text { Switching easily between online dictionaries in } \\
\text { many languages. }\end{array}$ \\
\hline Kahoot & Kahoot! & https://kahoot.com & A game-based learning platform. \\
\hline Thinglink & e & https://www.thinglink.com/ & $\begin{array}{l}\text { Design multimedia rich learning materials } \\
\text { including text, image, video, recording, etc. }\end{array}$ \\
\hline WebRhubarb & & $\begin{array}{l}\text { https://www.cict.co.uk/text } \\
\text { oys/rhubarb.php }\end{array}$ & $\begin{array}{l}\text { Creating a web page which displays the text with } \\
\text { most of the characters replaced by blanks. }\end{array}$ \\
\hline WebSequitur & & $\begin{array}{l}\text { https://www.cict.co.uk/text } \\
\text { oys/sequitur.php }\end{array}$ & $\begin{array}{l}\text { Reconstructing a text which has been broken } \\
\text { into segments. }\end{array}$ \\
\hline Google sites & & https://sites.google.com & $\begin{array}{l}\text { A wiki- and Web page-creation tool offered by } \\
\text { Google. }\end{array}$ \\
\hline \begin{tabular}{|l|} 
SMART \\
Learning \\
Suite (SLS) \\
\end{tabular} & & $\begin{array}{l}\text { https://suite.smarttech.com } \\
\text { /library }\end{array}$ & Creating lessons, activities and assessments. \\
\hline Classflow & & https://classflow.com/ & $\begin{array}{l}\text { Creating interactive lessons, resources, and } \\
\text { activities. }\end{array}$ \\
\hline Edpuzzle & edpuzzle & https://edpuzzle.com/ & Creating interactive video lessons and quizzes. \\
\hline Quizlet & Q & https://quizlet.com/ & $\begin{array}{l}\text { A memorization tool that enables learners to } \\
\text { memorize vocabulary via various game-based } \\
\text { activities such as flashcards, write, speller, } \\
\text { match, gravity mode and live. }\end{array}$ \\
\hline Google Forms & :E & $\begin{array}{l}\text { https://www.google.com/fo } \\
\text { rms/about/ }\end{array}$ & $\begin{array}{l}\text { Creating online surveys and quizzes and send } \\
\text { them to other people. }\end{array}$ \\
\hline Google Docs & $\equiv$ & https://docs.google.com & Word processing online tool. \\
\hline WeVideo & D WEVIDeO & https://www.wevideo.com/ & $\begin{array}{l}\text { A collaborative, web-based video editing } \\
\text { platform which works in any browser. }\end{array}$ \\
\hline
\end{tabular}


iii- The selected Web 2.0 tools were categorized according to their functionality in line with the seven principles of good practice in undergraduate education (Chickering \& Gamson, 1989). Participants in the experimental group were provided with tutorials to use those tools in the classroom or through synchronous and asynchronous web sessions.

iv- SAMR model (Puentedura, 2013) was used to match the selected Web 2.0 tools with the learning objectives in each unit.

$v$ - The content was presented in a user-friendly website that enables all learners, whether "digital natives" or "digital immigrants" (Prensky, 2009) to access the materials and do all activities. For this purpose, we have initially used google sites and the activities created by various Web 2.0 tools were embedded into the website so that students can do activities straight in the website and they do not need to move from one tool or page to another.

The data was collected over 12 weeks; 3 hours for each group. The research design can be graphically represented in the following diagram.

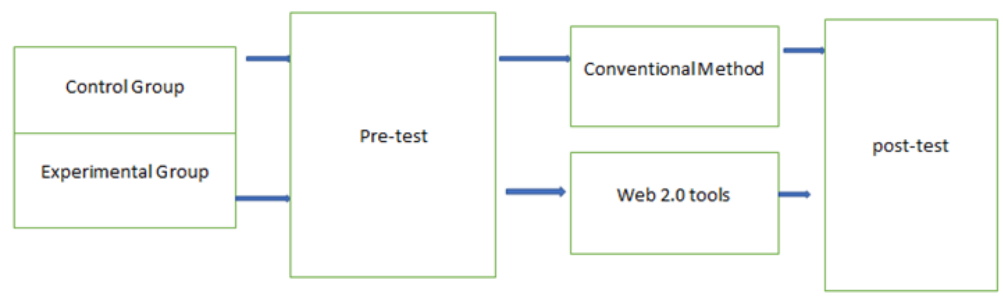

Figure 3: Research Design

A pre-test was given to the two groups in the beginning of the experiment and a post-test was administered at the end of the $12^{\text {th }}$ week. The period between the two tests were therefore sufficient to decrease the effect of the pre-test over the results of the post-test. The test consisted of the following components:

i- A reading comprehension text.

ii- A listening comprehension text.

iii- A writing component.

iv- A dialogue with a number of missing blanks.

v- A vocabulary question.

The test was sent to three specialists at the Center of Languages and Translation, Taiz University, Yemen and the answers of participants were marked out of 100 by them. Out of the different types of blended learning (Hannon \& Macken, 2014), the Blended Block model (sometimes called a Programme Flow model) was used while teaching the experimental group. In this model, a sequence of activities, or "blocks," is structured to incorporate both face-to-face learning and online study.

\section{Results and Discussion}

To test the first hypothesis; "the use of Web 2.o tools can enhance the language skills (i.e., reading, writing, speaking and listening) as well as the vocabulary of the learners of Arabic as a foreign language", we have done descriptive statistics for the post-test. Table 2 shows the mean scores of both control and experimental groups' post-test. The experimental group had higher mean score (73.40oo) in comparison to the control group (65.400o). Thus, the first hypothesis is accepted. 
Table 2: Descriptive Statistics of the Post-test for the Two Groups

\section{Descriptive Statistics}

\begin{tabular}{l|c|c|c|c|c} 
& $\mathrm{N}$ & Minimum & Maximum & Mean & Std. Deviation \\
\hline Post-test Reading Control & 15 & 12.00 & 16.00 & 14.2667 & 1.33452 \\
\hline Post-test Reading Experimental & 15 & 14.00 & 17.00 & 15.5333 & .91548 \\
\hline Post-test Writing Control & 15 & 11.00 & 15.00 & 13.4667 & 1.24595 \\
\hline Post-test writing Experimental & 15 & 13.00 & 16.00 & 14.8667 & .91548 \\
\hline Post-test Speaking Control & 15 & 10.00 & 16.00 & 13.2667 & 1.86956 \\
\hline Post-test Speaking experimental & 15 & 13.00 & 17.00 & 15.4667 & 1.30201 \\
\hline Post-test Listening Control & 15 & 6.00 & 15.00 & 10.6000 & 2.06328 \\
\hline Post-test Listening Experimental & 15 & 10.00 & 17.00 & 14.2667 & 1.83095 \\
\hline Post-test Vocabulary Control & 15 & 10.00 & 17.00 & 12.0667 & 2.65832 \\
\hline Post-test Vocabulary Experimental & 15 & 11.00 & 20.00 & 14.4667 & 2.87518 \\
\hline Post-test Control Total & 15 & 55.00 & 78.00 & 65.4000 & 7.70714 \\
\hline Post-test Experimental Total & 15 & 60.00 & 88.00 & 73.4000 & 7.95344 \\
\hline Valid N (listwise) & 15 & & & & \\
\hline
\end{tabular}

To test whether the difference between the two groups was statistically significant, a one-way analysis of covariance (ANCOVA) was conducted. The pre-test scores were used as the covariate variable. Before conducting the ANCOVA, we had to check that all assumptions are in place. First, we checked that there is no statistically significant difference between the control group and the experimental group on the pre-test, as is shown below.

Table 3: Tests of Between-Subjects Effects

\section{Tests of Between-Subjects Effects}

Dependent Variable: Pre-test

\begin{tabular}{lc|c|c|c|c} 
Source & Type III Sum of Squares & Df & Mean Square & F & Sig. \\
\hline Corrected Model & $13.333^{\mathrm{a}}$ & 1 & 13.333 & .236 & .631 \\
\hline Intercept & 111874.133 & 1 & 111874.133 & 1979.406 & .000 \\
\hline Group & 13.333 & 1 & 13.333 & .236 & .631 \\
\hline Error & 1582.533 & 28 & 56.519 & & \\
\hline Total & 113470.000 & 30 & & & \\
\hline Corrected Total & 1595.867 & 29 & & & \\
\hline
\end{tabular}

a. R Squared $=.008$ (Adjusted R Squared $=-.027$ )

As table 3 shows the group significance was found to be 0.631 and thus there is no statistically significant difference between the control and the experimental groups on the pre-test. We have also checked the assumption of homogeneity of regression as follows:

Table 4: Tests of Between-Subjects Effects

Tests of Between-Subjects Effects

Dependent Variable: Post-test

Source

Type III Sum of Squares \begin{tabular}{l|l|l|l} 
Df & Mean Square & F & Sig. \\
\hline
\end{tabular}

\begin{tabular}{l|c|c|c|c|c}
\hline Corrected Model & $1463.909^{\mathrm{a}}$ & 3 & 487.970 & 17.302 & .000 \\
\hline Intercept & 187.301 & 1 & 187.301 & 6.641 & .016 \\
\hline Group & 70.780 & 1 & 70.780 & 2.510 & .125 \\
\hline Pre-test & 974.349 & 1 & 974.349 & 34.547 & .000 \\
\hline Group * Pre-test & 30.706 & 1 & 30.706 & 1.089 & .306 \\
\hline Error & 733.291 & 26 & 28.204 & & \\
\hline Total & 146688.000 & 30 & & & \\
\hline Corrected Total & 2197.200 & 29 & & & \\
\hline
\end{tabular}

a. R Squared $=.666$ (Adjusted R Squared $=.628$ ) 
Table 4 shows that Group * Pre-test is .306. That is, it is not statistically significant and thus it meets the homogeneity of regression condition and we can go forward with the ANCOVA test. The results of ANCOVA are given below:

Table 5: ANCOVA Results of the Pre and Post Test

\section{Descriptive Statistics}

Dependent Variable: Post-test

\begin{tabular}{lc|c|c} 
Group & Mean & Std. Deviation & N \\
\hline Control & 65.4000 & 7.70714 & 15 \\
\hline Experimental & 73.4000 & 7.95344 & 15 \\
\hline Total & 69.4000 & 8.70434 & 30 \\
\hline
\end{tabular}

ANCOVA Results of the Pre and Post Test

Dependent Variable: Post-test

\begin{tabular}{lc|c|c|c|c|c} 
Source & Type III Sum of Squares & Df & Mean Square & F & Sig. & Partial Eta Squared \\
\hline Corrected Model & $1433.203^{\mathrm{a}}$ & 2 & 716.601 & 25.325 & .000 & .652 \\
\hline Intercept & 202.646 & 1 & 202.646 & 7.162 & .013 & .210 \\
\hline pre-test & 953.203 & 1 & 953.203 & 33.687 & .000 & .555 \\
\hline Group & 607.092 & 1 & 607.092 & 21.455 & .000 & .443 \\
\hline Error & 763.997 & 27 & 28.296 & & & \\
\hline Total & 146688.000 & 30 & & & & \\
\hline Corrected Total & 2197.200 & 29 & & & & \\
\hline
\end{tabular}

a. $\quad$ R Squared $=.652$ (Adjusted R Squared $=.627$ )

Table 5 shows the results of the ANCOVA test. The results revealed that there was a statistically significant difference between the two groups in the post-test $(\mathrm{F}=21.455 ; \mathrm{p}=.000$; partial Eta squared= .443) in favour of the experimental group. Consequently, using Web 2.o tools improved students' language skills and their vocabulary comparing to the traditional teaching method and hence the second hypothesis is rejected. The above results can be graphically represented as follows.

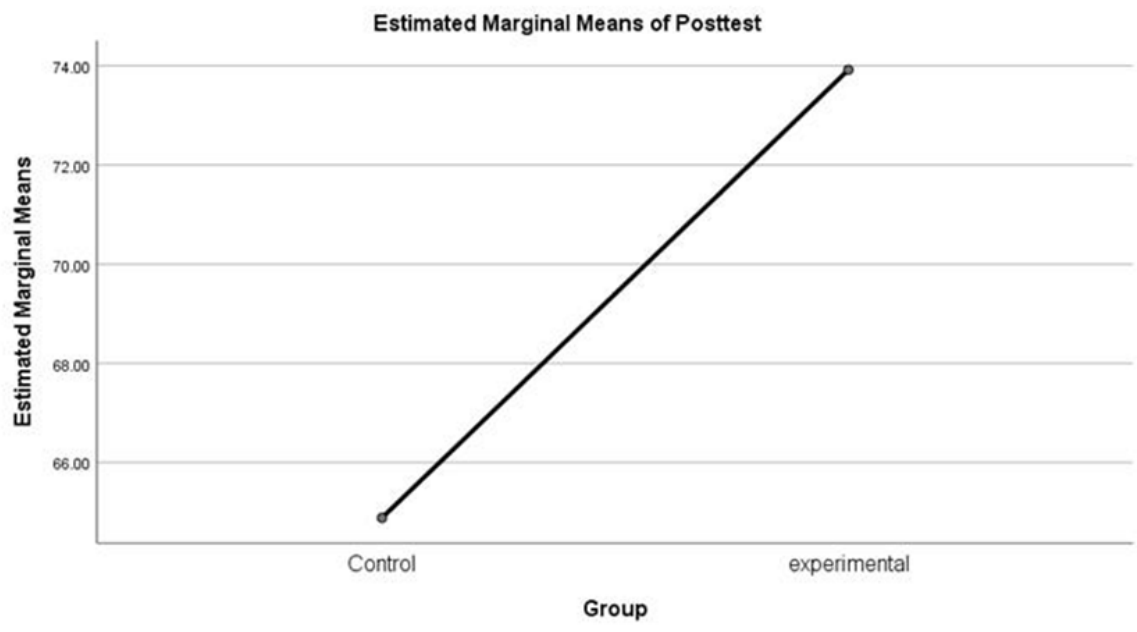

Covariates appearing in the model are evaluated at the following values: Pretest $=61,0667$

Figure 4: Estimated Marginal Means of Post-test 


\section{Conclusions}

The findings of the study showed that using Web 2.0 tools improved students' receptive and productive skills comparing to the traditional teaching methods. This improvement is due to the potentials that Web 2.0 tools can offer to learners. They provide students with opportunities to practice various skills inside and outside the classroom. The findings have shown that the use of Web 2.o tools has improved the achievement of students in listening skills. The tools have motivated them to watch/listen to the listening videos/recordings and do the interactive listening comprehension activities in each unit.

The use of those tools has also enhanced their writing skills. This is evident in their participation in the lesson forums and in the findings of the study. Web 2.0 tools have also encouraged the learners to interact and chat with their peers. Students used Vocaro to record their opinions on certain topics and they shared them with their peers.

The tools have also assisted the students in their reading skills and their vocabulary. Students have developed more awareness towards the use of some literary/figurative expressions, collocations and proverbial statements. Besides, using Web 2.0 tools such as Multidic saved students' time and enabled them to look up the words immediately in different dictionaries and corpora.

The use of such tools has also facilitated flipped learning. Students were requested to do prereading activities before coming to the class. For instance, the use of quizlet to gamify the study of new vocabulary has proven to be very useful to the learners. The comprehension of the reading text has become easier and more accessible to them.

Web 2.o tools have also planted the seeds of competition among the learners. They have enabled them to be more creative in their assignments, as is clear from the digital storytelling projects produced by the learners.

As this paper is based on a small-scale study, conclusions drawn on the impact of Web 2.0 tools in teaching foreign language skills remain tentative. Further studies with a larger group of differing levels, languages, linguistic backgrounds, age groups and populations are needed to reach more comprehensive conclusions about the effective integration of Web 2.0 tools in the syllabus.

\section{References}

Abdul-Hameed, M., \& Khawalidah, A. (2018). Fā'ilyat barnamaj ta 'īmī qā'im 'Tā al-ta 'alum al-tasharūkì 'abr'

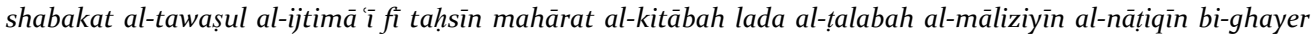
al- 'arabyah. Al-Dirasat: Educational Sciences, 45(4), 17-45.

Abdullah, A. al-Shaykh. (2015). 'Itijahāt Al-Mudarisīn Wa al-Ṭalabah Fī Burnaay Dār al-Salām Naḥwa Istikhdām Shabakāt Al-Tawașul Al-Igtimā' '̄ Fī Ta līm al-Lughah Al-'arabiyah'. Majalat Al-Dirāsāt Al-Lughawiyah Wa Al-Adabiyah, (5), 117-44.

Augustsson, G. (2010). Web 2.0, pedagogical support for reflexive and emotional social interaction among Swedish students. The Internet and Higher Education, 13(4), 197-205.

Azab, N., Abdelsalam, H. M., \& Gamal, S. (2013). Use of Web 2.o collaboration technologies in Egyptian public universities: An exploratory study. In E-government implementation and practice in developing countries (pp. 99-127). IGI Global.

Blattner, G., \& Lomicka, L. (2012). Facebook-ing and the social generation: A new era of language learning. Alsic. Apprentissage Des Langues et Systèmes d'Information et de Communication, 15(1). Retrieved from https://journals.openedition.org/alsic/2413

Bloom, B. S. (1956). Taxonomy of educational objectives: The classification of educational goals. Longman.

Borau, K., Ullrich, C., Feng, J., \& Shen, R. (2009). Microblogging for language learning: Using twitter to train communicative and cultural competence. International Conference on Web-Based Learning, 78-87. Springer.

Brenner, K. (2014). Digital Stories: A 21st-Century Communication Tool for the English Language Classroom. English Teaching Forum, 52, 22-29. ERIC.

Chickering, A. W., \& Gamson, Z. F. (1989). Seven principles for good practice in undergraduate education. Biochem. Educ., 17(3), 140-141. 
Cisco. (2012). Cisco Visual Networking Index: Global Mobile Data Traffic Forecast Update, 2011-2016. San Jose, Calif.

Cisco. (2019). Cisco Visual Networking Index: Global Mobile Data Traffic Forecast Update, 2017-2022. Retrieved from Cisco Mobile VNI website: https://www.cisco.com/c/en/us/solutions/collateral/serviceprovider/visual-networking-index-vni/white-paper-c11-738429.html

Flores, J. F. F. (2015). Using gamification to enhance second language learning. Digital Education Review, (27), 3254.

Ghalib, M., \& Sabri, M. (2012). 'Ta' līm Al-Lughah Al-'arabiyah 'abr Al-Wasā'at Al-Muta didah Wa 'alaqatiha BiAlta 'līm Al-Hasūbī 'ala Dau Al-Naẓariyah Al-Idrākiyah'. Majalat Al-Dirāsāt Al-Lughawiyah Wa Al-Adabiyah, 106-34.

Hafner, C. A., \& Miller, L. (2011). Fostering learner autonomy in English for science: A collaborative digital video project in a technological learning environment. Language Learning E Technology, 15(3), 68-86.

Hannon, J., \& Macken, C. (2014). Blended and online curriculum design toolkit. Retrieved from https://www.latrobe.edu.au/_data/assets/pdf_file/ooo6/602178/Blended-learning-Toolkit-v4.pdf

Hew, K. F., \& Cheung, W. S. (2013). Use of Web 2.0 technologies in K-12 and higher education: The search for evidence-based practice. Educational Research Review, 9, 47-64.

Kessler, G., Bikowski, D., \& Boggs, J. (2012). Collaborative writing among second language learners in academic web-based projects. Language Learning \& Technology, 16(1), 91-109.

Lee, L. (2010). Exploring wiki-mediated collaborative writing: A case study in an elementary Spanish course. Calico Journal, $27(2), 260-276$.

Light, D., \& Polin, D. K. (2010). Integrating Web 2.o Tools into the Classroom: Changing the Culture of Learning. Center for Children and Technology, Education Development Center, Inc.

Luo, T. (2013). Web 2.0 for language learning: Benefits and challenges for educators. International Journal of Computer-Assisted Language Learning and Teaching (Ijcallt), 3(3), 1-17.

Marty, F. (2008). Reflections on the use of computers in second language acquisition. System, 9(2), 85-98.

Mc Dermott, G. (2013). The role of social media in foreign language teaching: A case study for French. Recherche et Pratiques Pédagogiques En Langues de Spécialité. Cahiers de l'Apliut, 32(2), 141-157.

Mohammed, T. A. S. (2011). A taxonomy of problems in Arabic-English translation: A systematic functional grammar approach (PhD Thesis). University of the Western Cape, Cape Town, South Africa.

O'Reilly, T. (2005). What is Web 2.0. Design patterns and business models. O'Reilly. Retrieved from https://www.oreilly.com/pub/a/web2/archive/what-is-web-2o.html

Prensky, M. (2009). H. sapiens digital: From digital immigrants and digital natives to digital wisdom. Innovate: Journal of Online Education, 5(3). Retrieved from https://www.learntechlib.org/p/104264/

Puentedura, R. R. (2013). SAMR: Moving from enhancement to transformation [Web log post].

Rabii, A. M. (2017). Tauẓîf Wasā'al Al-I'lām Wa Al-Tiknūlūjiah Al-Ḥadithah Fī Ta 'līm Al-Lughah Al-'arabiyah LiNaṭiqīn Bi-Ghirihā: Dirasah Tạ̣līliyah',. Majalat Al-Dirāsāt Al-Lughawiyah Wa Al-Adabiyah, (9), 56-68.

Reinhardt, J., Warner, C., \& Lange, K. (2014). Digital games as practices and texts: New literacies and genres in an L2 German classroom. Digital Literacies in Foreign and Second Language Education, 159-177.

Robin, B. R. (2008). Digital storytelling: A powerful technology tool for the 21st century classroom. Theory into Practice, 47(3), 220-228.

Sandars, J., \& Schroter, S. (2007). Web 2.o technologies for undergraduate and postgraduate medical education: An online survey. Postgraduate Medical Journal, 83(986), 759-762.

Shehreer, S., \& Abdul-Ghani, M. (2016). Tașmīm Barnāmij Hasūbi Li-Ta līm Al-Lughah Al-'arabiyah 'abr Ma'uqi ' Iliktrunī Li-Darisīn Al-Mutakhșisīn Fī Al-Siyāḥah Bi-Kuliyat Marā Li-Tiqniyah Bi-Wilayat Klintān Dār Al$\mathrm{Na}$ '̄im Bi-Maliziyā'. Majalat Al-Dirāsāt Al-Lughawiyah Wa Al-Adabiyah, (7), 42-73.

Surowiecki, J. (2005). The wisdom of crowds. Anchor.

Trados, Sdl. (2015). SDL Certification: Post-Editing Certification. SDL.

UNESCO. (2017). The future of mobile learning. Retrieved from http://www.waccglobal.org/articles/the-future-ofmobile-learning

Vurdien, R. (2013). Enhancing writing skills through blogging in an advanced English as a Foreign Language class in Spain. Computer Assisted Language Learning, 26(2), 126-143.

Zimmerman, E. (2008). Gaming literacy: Game design as a model for literacy in the twenty-first century. In The video game theory reader 2 (pp. 45-54). Routledge. 